Article

\title{
Beyond the Nation-State? The Ideology of the Esperanto Movement between Neutralism and Multilingualism
}

\author{
Federico Gobbo ${ }^{1,2,3}$ \\ ${ }^{1}$ Amsterdam Center for Language and Communication (ACLC), University of Amsterdam, 1012 VB Amsterdam, \\ The Netherlands; E-Mail: f.gobbo@uva.nl \\ 2 Department of Humanities (StudiUm), University of Turin, 10124 Torino, Italy; E-Mail: federico.gobbo@unito.it \\ 3 Department of Educational Human Sciences “Riccardo Massa”, University of Milano-Bicocca, 20126 Milan, Italy
}

Submitted: 18 August 2017 | Accepted: 31 October 2017 | Published: 22 December 2017

\begin{abstract}
Since its launch, Esperanto has attracted people involved in language politics. For them Esperanto provides an equitable solution when international problems are discussed, overcoming the barrier posed by the use of national languages and identities. However, its relation with the nation-state is far from being straightforward. Although a significant majority of the Movement claims Esperanto to be a neŭtrala lingvo, a neutral language, this has been fiercely contested by Esperanto activists committed to advancing particular programs for changing the world. From a sociolinguistic point of view, all Esperanto speakers are at least bilingual and quite often multilingual, without exception, so they always belong at least to one speech community in some way connected with a nation-state. This article illustrates the different facets of the Esperanto Movement from its beginning in 1887. Particular attention is paid to the concept of neutralism and how it has evolved in time. From the belle époque, Esperanto has been forced to re-define its position according to changes in sociopolitical contexts. In the current era of 'glocalization', where the spread of English worldwide is counterbalanced with old and new forms of local identities often linked with minority languages, Esperanto represents an alternative to the idea that global English leads to more social inclusion.
\end{abstract}

\section{Keywords}

Esperanto; globalization; glocalization; language; language politics; linguistic justice; minority language; mobility; nationstate; neutral language

Issue

This article is part of the issue "Multilingualism and Social Inclusion”, edited by László Marácz (University of Amsterdam, The Netherlands/Gumilyov Eurasian National University, Kazakhstan) and Silvia Adamo (University of Copenhagen, Denmark).

(C) 2017 by the author; licensee Cogitatio (Lisbon, Portugal). This article is licensed under a Creative Commons Attribution 4.0 International License (CC BY).

\section{Introduction}

The traditional Westphalian model of the relation between nationalities and languages has been challenged in recent years-for instance, by Beaulac (2004)-for failing to account for the complexity of language and identity in the contemporary world. According to that model, languages are homogeneous, and citizens of a given nation-state are monolingual: sociolinguistic variations and multilingual areas due to the presence of minority languages are a threat to the social cohesion of the nation-state. The aim of this article is to present the multi-faceted ideology of Esperanto, historically one of the first critiques of the Westphalian model. In particular, we will delve into the relation between Esperanto language loyalty and the Esperanto speakers' sense of belonging to their respective nation-states is examined. Methodologically, three analytical approaches have been used to this end: first, the author's observation of the Esperanto community over the last 20 years, using the analytical tools of linguistic anthropology; second, discourse analysis of the most influential texts presenting the ideologies involving Esperanto; third, sociology of language and sociolinguistics, as language-in-use 
reveals some distinct aspects which are relevant to our study. The main thesis of the article is that Esperanto identity is far more complex and fluid than the monolithic presentation often found in accounts on the phenomenon written by people outside the Esperanto community. In particular, the ideological positioning of the role played by the nation-state and religion as entities fostering social cohesion-and therefore permitting social inclusion-have dramatically changed since the early days of the Esperanto community.

Esperanto is a planned language created in 1887 by Ludwig Lejzer Zamenhof, an Ashkenazi Jew living in the Tsarist Empire. The term 'planned language' (Blanke, 1989) refers to languages invented by a single person to be suitable for human communication. The main difference between planned and natural languages is that natural languages respect the historical priority of speech, while planned languages-along with sign languages-do not (Gobbo, 2012). In other words, artificiality in planned languages is only a matter of degree (Stria, 2016). However, what they lack when they are published-yesteryear in a book, nowadays on a web site-is a community of speakers. The vitality of various planned languages after publication was measured by Blanke $(1989,2006)$ according to their success among the public. Most planned languages remain in the project phase: their vitality relies entirely on their language planners, and therefore when they die, their linguistic creations are no longer in use, and their names are known only by specialists and aficionados. A few projects survive their language planners thanks to a community of practice formed around the planned language itself. According to Eckert (2006), a community of practice is a group of people involved in a social practice that defines their sense of belonging, regardless of their sociological traits (e.g., class, gender, ethnicity) or co-presence (e.g., place of living or workplace). A typical example is the community of practice of chess players, who define themselves by playing chess (the object level) and talking about chess and its philosophy (the meta-level): this process of collective sense-making builds their sense of belonging, which comprises specific cultural traits, including a jargon and a distinct sense of humour, often expressed through specific metaphors (Astori, 2015). In our case, it is the practice of using the planned language that forms the community (Janton, 1993). It is important to note that speakers of planned languages are always multilingual; in other words, monolingual speakers of planned languages do not exist. Therefore, belonging to a community of practice of a planned language implies practicing some form of multilingualism. In the case of Esperanto, attitudes towards multilingualism have changed dramatically over time. In particular, there is a stigma in applying code-switching and code-mixing strategies while speaking in Esperanto, represented by the metaphorical use of krokodili, i.e., "to behave like a crocodile" (Astori, 2015, p. 141).
While in the 20th century there were some consistent communities of practice for rival languages of Esperanto, such as Ido (Garvía, 2015), nowadays new communities of practice are formed around Hollywood languages, such as Dothraki (Gobbo, 2017; Peterson, 2015). In any case, there is a wide consensus that only Esperanto can be considered a fully-fledged planned language, because of the size of its community of practice. Estimates vary, but even the lowest figures number around 10,000 active speakers, while people being in contact with the language through online courses such as Duolingo (2017) are more than a million. Moreover, as of 2017, the community has enjoyed 130 years of uninterrupted use. Most commentators cite three factors for the relative success of Esperanto over its rivals. The first factor is its time of publication (1887), as all rivals appearing afterwards had to compete with an already established Movement (Large, 1985), i.e., a set of non-governmental institutions representing the language outside the community of practice as well as providing services for its members. The second and perhaps most important factor is the Esperanto language representation, that is, the discourse made by the Esperanto community of practice on the meta-level, expressed in discourse and documentation by members directly in the language itself. Language ideology is an important part of language representation, and is formed by the set of purposes, objectives and goals that supporters associate with the language itself, in response to the external public. The third factor is the linguistic structure of Esperanto, which is so clear and regular in its general lines that anyone can start to use it after a little study. The exact amount of time for acquisition varies according to a student's repertoire, motivations, and other variables (Gobbo, 2017). In the rest of this article, we will mainly explore the second factor, which is the Esperanto language representation, examining how it was re-defined by the community of practice and presented to the general public according to the varying contexts of the times. In particular, the concept of 'neutrality', in a positive and negative sense, is discussed as well as how this relates to the image of the nation-state from Esperanto supporters' point of view. Finally, the possible role of Esperanto in fostering social inclusion is investigated.

We can identify five main historical periods of the life of Esperanto: the pioneers' period, when Zamenhof, the Esperanto language planner, was still alive (1887-1917); the interwar period, when a distinct left-winged Esperanto Movement emerged (1917-1939); the persecution period, when Esperanto was considered a "dangerous language" (Lins, 2017) by totalitarian regimes and persecuted during the Second World War (1939-1945); the modern period, when the Esperanto Movement was reconstructed in the aftermath of the war (since 1946). While it is possible to distinguish different sub-periods after the Second World War, for the purpose of this paper a uniform modern period suffices. 


\section{Zamenhof's Philosophy of 'Neutrally-Human Language'}

To understand a planned language, it is necessary to start with the language planner, whose role is crucial, especially after publication. After publication the first phase of the vitality of the planned language starts, when it is just a project. Ludwig Lejzer Zamenhof was born in Białystok in 1859. At that time Poland did not exist on the political map of Europe, being part of the Tsarist Russia. As he recalled in a famous letter, his city was divided into four ethnic group and religions as well: the Jews, who were the majority and who practiced their own religion; the Russians, who held the political power, Orthodox Christians and Catholic Poles, who struggled for political independence; and finally, a minority group of German Protestants. According to Zamenhof's biographer, Korzhenkov (2010), Esperanto was only part of a larger philosophical project which aimed at renewing humankind. Zamenhof, looking through the lens of the Haskalah movement, the Jewish version of the Enlightenment, saw two barriers that impeded human beings live from living in "perpetual peace" as postulated by Immanuel Kant: the diversity of religions and the diversity of languages. As a Jew, he initially proposed his philosophical project to his own people. He envisioned Jews as founding Israel on the banks of the Mississippi River, similar to what the Mormons had already done in Utah. He thought they should speak a new language that reflected the Slavic-Germanic spirit of Yiddish as well as the Sefardi languages, which were influenced by Romance languages and Greek. Jews and non-Jews alike were to learn this language to communicate on an equal footing, thus promoting a "neutrally-human" culture. This kind of culture was to be based on the universal values of monotheistic religions, with neutral rituals, calendars, temples and festivities to be shared by all the believers of monotheistic religions. The adepts of this way of life would form speech communities in urban areas of tolerant countries, such as Switzerland. Zamenhof initially published his proposal in Russian, calling his moral philosophy 'Hillelism'. The name comes from Hillel the Elder, an important Jewish figure at the time of Jesus (Cherpillod, 2005). Zamenhof believed that Hillelists - the adepts of Hillelism - would all be multilingual, speaking Esperanto in their circle, the language(s) of their hosting culture in the public sphere and their heritage languages among family members. However, Hillelism was of limited interest to Jews living in Russia in the last part of the 19th century, as proto-Zionism held more appeal for them.

Hillelism was Zamenhof's solution to the Jewish question, where Jews and non-Jews could live side-by-side in peace and respect for each other. That solution appeared unrealistic to most Jews at that time. There is some parallelism between the revitalization of $\mathrm{He}$ brew and the promotion of Esperanto, as both protoZionism and the Esperanto Movements were formed in the same years (Halperin, 2012, Künzli, 2010). Zamen- hof played a minor role in Zionism's early days (Gishron, 1986; Holzhaus, 1969; Maimon, 1978). Unlike Eliezer Ben-Yehudah, the father of Modern Hebrew, Zamenhof did not believe that Hebrew could be fully revitalized. History proved Zamenhof wrong, as Modern Hebrew is now a fully naturalized language (Berdichevsky, 2014). The more the destinies of Jews were linked with Palestine and Israel's foundation of Israel there, the more Hillelism lost its appealing among (Russian) Jews, and the more Zamenhof took distance from Zionism. In the last years of his life, Zamenhof re-defined his philosophy in a new form, without any reference to Jewishness. The new version of his moral philosophy was named Homaranismo, which is Esperanto for "a brotherhood of humanity", and, although published in Esperanto, Zamenhof believed it should be transcribed in the major languages of the world, for its message was not limited to the Esperanto community (Korzhenkov, 2010). In this new version, there were no more references to neutral temples or to calendars or speech communities to be formed: the whole philosophical proposal became a code of conduct for single individuals rather than a political project. It proposed a sort of practical monotheism, suitable for both believers and non-believers. The role of the other languages is unclear; however, the more Esperanto was spoken, the less the other languages would be used for international communication. In any case, Zamenhof's efforts were mainly directed to promoting his "neutrally-human language". By 'neutrality' Zamenhof meant that the language belonged to anyone who wanted to adopt it, regardless of his or her nationality or religious beliefs: Esperanto speakers would not converse as members of a definite nation but in a big human family circle, like brothers and sisters. Though not strictly a political stand, the consequences of this position proved to be very controversial, resulting in Esperanto becoming the language of pacifism and anti-chauvinism.

According to Van Parijs' view of global linguistic justice, Esperanto is not a neutral language, as it is "very far from being neutral in the demanding sense of being equidistant from all existing languages" (Van Parijs, 2011, p. 40). We have one such language, Loglan (Cooke Brown, 1960), based on a statistical equidistance from all languages of the world. Its spectacular failure-along with its offspring Lojban - shows that planning a language on a statistical basis results in an idiom so obscure and cryptic that it lacks any appeal for learning (for an account, see Okrent, 2010). Esperanto's main rivals in the 20th century almost invariably eliminated its Slavic and drastically reduced its Germanic traits, citing Latin and Romance languages as the foundation of Western civilization. Most language planners were intellectuals and scholars living in Western countries, such as France or the United States. On the contrary Zamenhof's primary target population were Jews and non-Jews living in Europe, speaking Germanic, Slavic and Romance languages, the three language family groups which Esperanto is based on, at least for its lexicon (Gledhill, 2000, p. 20). 
Compared to its rivals, Esperanto is more neutral than its rivals.

We argue that we should distinguish absolute neutrality, i.e., the "equidistance" advocated by Van Parijs, from ethnic neutrality. Absolute neutrality is virtually impossible, as nobody knows all the 7,099 living languages (Simons \& Fennig, 2017). Ethnic neutrality implies that the language belongs to its community of practice, as defined above, where ethnicity plays no part in acceptance by the group. The Esperanto Movement built its language representation and ideology upon this ethnic neutrality. Absolute neutrality, though theoretically appealing, is infeasible and should be discarded.

\section{The Definition of Neutrality in the Pioneer Esperanto Movement}

The Esperanto Movement is the collection of men and women - the latter being a consistent percentage (33\% circa) of the total since its early days (Garvía, 2015)belonging to the Esperanto community of practice (i.e., Esperanto speakers) as well as the "friends" of the language, i.e., people who may or may not use the language but nevertheless support the idea (i.e., Esperantists). It is important to emphasize that Zamenhof's philosophy was rejected by the vast majority of his contemporaries as being too radical, and in particular a possible threat to the Westphalian model as cited in the Introduction. Therefore, Esperanto became a home for very different ideologies linked to the languages, according to varying historical contexts. In other words, the only prerequisite for belonging to the Esperanto Movement was to support the language without introducing structural changes that could jeopardize the consistency of the language itself. Changing a part of the grammar, for example the pronominal system and the gender balance, would constitute de facto a new planned language project derived from Esperanto. In the first decades of the 20th century there were dozens of such projects, variably called "reforms" or "improvements" of Esperanto (Garvía, 2015). In particular, one of them, Ido, gained the attention of some European scholars and intellectuals until the First World War (Gordin, 2015). While rivals were challenging the existence of Zamenhof's creation, the Esperanto Movement started to define Esperantism, i.e., its language ideology as articulated by its supporters. A key trait of the mainstream Esperantism is political and ideological neutrality. In fact, in the first World Esperanto Congress organized in Boulogne-surMer, France, in 1905, participants formulated the Declaration of Esperantism, in which Article 1 states:

Esperantism is the endeavour to spread worldwide the use of this neutral, human language which, "not intruding upon the personal life of peoples and in no way aiming to replace existing national languages", would give to people of different nations the ability to understand each other [...] All other ideals or hopes tied to Esperantism by any Esperantist is his or her purely private affair, for which Esperantism is not responsible. (Dietterle, 1929, p. 237, my translation from Esperanto)

Moreover, the Declaration of Esperantism (1905) states that Esperanto is nobody's property, in other words nobody can claim a copyright or put a trademark on the language. The text of the Declaration was left ambiguous in two key areas: first, how the Esperanto Movement was to influence the world in the public sphere; second, what the relation is between national identity and Esperanto identity. The word "Esperantist" is the traditional term used to indicate believers of Esperantism and therefore supporters of the Esperanto Movement, even if they do not actively use the language. This term is sometimes contested by some Esperanto speakers, who define themselves "Esperantophones", to emphasize their belonging to the community of practice while not sharing the ideals of the Esperanto Movement. For them, the value of Esperanto depends on the language itself and in its active use, regardless of its impact on the world outside the community.

Since 1905, the debate within the Esperanto Movement has raged as to what exactly "neutral language" means (Sikosek, 2006). Francophone Esperantists, the most important groups in the early days of the 20th century, came up with two different interpretations of neutralism based on the Declaration in Boulogne: Swiss neutralism and French neutralism. The key figure of the first interpretation was Hector Hodler, who founded the Universal Esperanto Association (UEA) in Geneva, in 1908. For him, the UEA was to be the "Red Cross of the Soul", and membership was granted on an individual basis. His aim was to establish a network of "consuls" (konsuloj) to provide service for travelling Esperanto speakers, as well as a network of "cultural Esperanto centres" (KCE, Kultura Centro Esperantista) where to run year-long cultural programs in Esperanto and language coursessomething similar to the modern British Council for English or the Goethe-Institut for German. For Hodler, ethnicity in general and nationality in particular were not to play special roles in being Esperantist. The multilingualism of Esperanto speakers was taken for granted.

Esperantists in France had a different interpretation. As of the year 1900, the majority of Esperantists were no longer citizens of Russian territories but French, according to the membership listing of Esperanto associations (Garvía, 2015). When the centre of the Esperanto Movement shifted to France, Zamenhof understood that his philosophy could not be accepted by Esperantists, so he stepped down from the leadership of the Esperanto Movement. The key figure of this second interpretation, i.e., French neutralism, was Louis de Beaufront, the "second father of Esperanto" (Korjenkov, 2015), who founded the Society for the Propagation of Esperanto (SPPE) in 1898. He stressed the practical utility of the language and succeeded in gaining the attention of impor- 
tant figures in the French society of his time. His publications were mainly bilingual French-Esperanto, and Esperantists organized themselves in local clubs in cities and towns scattered around the country, with a national association as the head office (Garvía, 2015, p. 81). In his view, Esperantism was a secondary identity after nationality, and the organization of Esperanto Movement had to respect the borderlines lines of the political map, i.e., Esperantists had to be members of their own national Esperanto associations, not cosmopolitan associations like the UEA in Geneva. In other words, while Swiss neutralism emphasized Esperanto's role among individuals in creating a new world order in international relations, French neutralism considered the language as a bridge between nations, and perceived Esperanto as a commodity. In fact, French publications depicted the language as an instrument for doing things internationally in a more efficient way. Examples of this include publications of original scientific results, tourism, international commerce and diplomatic relations.

\section{The Interwar Period: Non-Neutrality in the Esperanto Movement Arises}

Since its beginning, Esperanto has attracted people who are inclined to change the world where they live through social engagement. For them, neither Esperanto's practical use (French neutralism) nor the vague secondary identity it conferred (Swiss neutralism) was enough. Instead, they saw the language as a means of advancing the world in a direction determined by an external ideology. We will consider collectively such Esperantisms as non-neutral. For example, the first nucleus of the International Vegetarian Movement met in Dresden in 1908, thanks to Esperantists who were also vegetarians (Sikosek, 2005). Perhaps the first consistent non-neutral Esperanto Movement was started by Catholics in 1902. Their idea was that the Christian Churches (Catholics, Protestant, Orthodox) could reunite by using a common language to spread the word of Christ (Matthias, 2002). There was a consistent presence of pacifists in the early days of the Esperanto Movement. Alcalde's research (2015a) showed that "we can find numerous supporters of the international language among the leaders of the main pacifist currents of the time: scientific pacifism, feminist pacifism, religious pacifism and proletarian internationalism". The World Esperanto Congress, planned for Paris in 1914 would have been the greatest congress of pacifists up to that time, but unfortunately it did not take place due to the outbreak of the First World War. Zamenhof died before the end of the war in 1917, some months before the Bolsheviks took power from the Tsar in Russia. His last public statement was very political: he published a bilingual EsperantoEnglish appeal to diplomats in 1915, urging the reconstruction of Europe along the lines of the United States of America. Esperanto-or another ethnically neutral language-would be the common language of the new political entity, shaping its linguistic landscape in order to abolish:

Racial names of the countries...for the unfortunate name will not only seem to justify the most despicable interracial abuses in those countries of eastern Europe where the races are mingled, but even in more civilised countries it will always warp the judgement of even the most right-minded citizens, ever perpetuating in them the belief and impression that the country belongs only to that race whose name it bears, and all its other races are but aliens there. (Zamenhof, 1915, p. 55)

Zamenhof's worldview admitted national identities if they do not claim to be superior by nature to others. In other words, patriotism was tolerable but chauvinism had to be eradicated.

After the end of the First World War, a non-neutral Esperanto Movement emerged, based on the new ideas of internationalism, whose first concrete manifestation was the USSR. A left-winged Esperanto Movement grew alongside and rivalled the neutral one. Anarchists, but also Socialists and Communists considered Esperanto an instrument for the emancipation of the proletariat. Proletarians were not to speak "bourgeois languages", which are inevitably nationally-based, but rather an ethnically neutral language. A neutral language could prevent the idea of war, a bourgeois phantasy built into national languages (Caligaris, 2016, p. 80). The main association fostering this non-neutral political interpretation was SAT (Worldwide Association of Anationalists), founded in Prague in 1921, the same year when many Communist parties were founded across Europe. Its founder was Eŭgeno Lanti-his name being adapted to Esperanto, Lanti meaning "I'anti", lit. "the one against". Lanti programmatically wanted to denounce the UEA's brand of Swiss neutralism as well as the national-based French neutralism as hypocritical and counter-productive (Lanti, 1922). Unlike Zamenhof, he considered national identities an absolute Evil per se, and therefore to be eliminated. The case could be made that national languages should be eliminated too as a direct consequence. We should remember that at that time Marr's linguistic theories were popular in the Soviet Union. For Marr, multilingualism was formed by the presence of different social classes, and when the proletarians unified the world, monolingualism would finally be a reality, and the world would speak only Russian (Yaguello, 1991, pp. 67-81). During the 1920s the various left-wing Esperantisms were relatively successful, but with the rise of totalitarian regimes in many countries across Europe, most notably Germany, Italy, and the Soviet Union, the two souls of the Esperanto Movements took different political directions. In fact, the neutral Esperanto Movement tried forging an impossible alliance with Hitler and Mussolini in the name of neutralism, but this did not prevent the Nazis and Fascists from banning Esperanto and its speakers. 
Relations with the Soviet Union were more complex; in any case, Stalin clearly persecuted Esperantists as prime suspects for passing information across Soviet borders (Lins, 2017; Minnaja, 2007). The limits of the Declaration of Boulogne emerged with tragic clarity when Gestapo agents learned Esperanto in order to infiltrate Esperantist groups and eventually had them killed in lagers. The persecution of Esperantists in extermination camps and gulags would forever change the Esperanto language representation. First of all, Esperantists would start considering themselves as victims: second, persecutions strengthened the idea that Esperanto was not just an intellectual hobby but, on the contrary, relevant, otherwise totalitarianisms would not care about it. After the Second World War, the Esperanto Movement was forced to rethink itself and its language ideology. The Second World War also demarcated a boundary in the relations between Esperanto and national identities: although Zamenhof tolerated patriotism and Swiss and French neutralisms did not contest the existence and relevance of nation-states, it is also true that the Esperanto ideology in all its facets proved to be incompatible with any form of racism, racial supremacy, and xenophobia.

\section{The Modern Esperanto Movement: From the Language Problem to the Acknowledgement of Multilingualism}

Eventually, in re-defining the Esperanto Movement, the French interpretation won over that of the Swiss one: nation-state boundaries became an unquestioned reality that re-formed the Esperanto Movement internally. The new worldwide association leading the Esperanto Movement since then has retained Hodler's original name for it, the UEA. It has acted as an international headquarters while at the same time accepting national Esperanto associations-along with their local clubs. The key figure of the new UEA was Ivo Lapenna. He wanted Esperanto to become a working language of the UN, using his personal contacts with diplomats. He did not succeed, but managed to obtain a resolution in 1954 (Resolution IV.4.422-4224) in favour of Esperanto because its results "correspond with the aims and ideals of Unesco". The UEA, thanks to his work, started to be in "Consultative arrangements with UNESCO 1962 Category B". Lapenna was fiercely against Communism, so UEA sided with the West under his leadership. Moreover, the UEA started to act as the point of reference for the national Esperanto associations on an international level: while the former had their respective nation-states as their horizon, UEA would deal with international institutions mainly. Consequently, Esperanto discourse recognized the role of the nation-state, and therefore it became normal to say "Dutch Esperantists" or "Italian Esperantists". Notably, the Esperanto political map does not always coincide with nation-state boundaries, as the cases of the Scottish and Catalan Esperanto societies demonstrate. In any case, even with these important exceptions, the re- ality of nation-states and the concept of nation in general would no longer be disputed. Unfortunately, the leftwing of the Esperanto Movement was drastically reduced in numbers after the Second World War, and this lead to the crisis of SAT, Eŭgeno Lanti's association, which would never again challenge UEA's leadership as the most important institution of the Esperanto world. To sign up as a member of both SAT and UEA became not unusual, unlike what had happened before the war. Lapenna did not consider Esperanto a variable in a multilingual panorama. He concentrated exclusively on formal relations among nation-states. He argued that the acceptance of a single national language for international communication was unrealistic, as the other nations would never accept it. Therefore, he considered multilingualism as a problem and Esperanto its solution (Lapenna, Lins, \& Carlevaro, 1974). After a decade, it became clear that English was increasingly being accepted as the de facto lingua franca on the Western side of the Iron Curtain, while Russian was the lingua franca on the other side. The initial enthusiasm for a rapid acceptance of Esperanto for diplomatic relations began to fade, while a new generation of Esperantists proposed different perspectives for the language. In 1956, a distinct "youth movement", the Worldwide Esperanto Youth Organization (TEJO), took shape within the UEA. In 1969, during a meeting of young Esperantists, the Declaration of Tyresö was signed, proposing a new interpretation of Esperantism.

If we apply with consistence the concept of conserving the integrity of individuals, you will condemn linguistic and cultural discriminations in any form, and also the so-called solution of the language problem, which is based on discrimination, and we find that until now we have not paid enough attention to the destruction of the cultural and linguistic background of many peoples. This destruction is nothing less than a tool of linguistic imperialism. (in Tonkin, 2006, p. 151, my translation from Esperanto)

This directly contrasts with Lapenna's view (see the "so-called solution" phrase) while also proposing Esperanto to protect minority language rights-even if it was unclear how to do this in practice. Since 1974, the most influential person in the Esperanto Movement is Humphrey Tonkin, who, beside his commitment to Esperanto, spent most of his academic career at the University of Hartford. He fostered the relationship between the Esperanto Movement and language rights. The organization of the renewed Esperanto Movement adhered to the political map of nation-states and therefore in principle was not particularly consistent in sustaining the rights of minority languages. However, there are some interesting exceptions: Catalan and Scottish associations do exist, distinct from Spanish and British respectively. Pietiläinen (2010) analyses the discourse regarding multilingualism in Esperanto publications. He found that in the 1970's there was Soviet influence in several Esperanto 
circles that denied the very existence of language conflicts in socialist states. Thus, the only remaining struggle for Esperantists on both sides of the Iron Curtain was the fight against the spread of English. In 1980 a new collective document came out by the new generation of young Esperantists, called Rauma Manifesto, from the town in Finland where it was signed. Their point of departure was the failure of the previous generations to get Esperanto officially recognized as a working language at the level of international institutions. Its role in UNESCO yielded no concrete results, apart from the mere recognition of the language by an external institution. The Rauma Manifesto was the most debated document in the Movement for at least twenty years, creating two ideological parties pro and con "Raumism", the ideology underlying it. Such as split had never occurred before, at least within the neutral Esperanto Movement. The following passage explains what and why it happened:

We believe that...the downfall of English is neither a task nor a concern of Esperantists: in the end English merely plays the role of an auxiliary language, like French in its time...: Zamenhof never proposed that the Movement fight against French, because he had in mind another, more valuable, alternative role for Esperanto....Esperantisticity [sic] is almost the same as belonging to a self-elected, diasporic, linguistic minority. (in Pietiläinen, 2010, p. 785, my translation from Esperanto)

The situation of the Jewish people before the foundation of Israel, the Diaspora, was used here as a metaphor for Esperanto speakers as a people with a language but no home. However, important distinctions should be made. In particular, attempts to find a territory to set up a state for Esperantists have sporadically been made for tiny territories, such as the Neutral Moresnet (Dröge, 2016), or the Island of the Rose (Astori, 2011), but have never been taken seriously by Esperantists. In particular, no Esperantist really moved there, like Jews did to Palestine. There is no "question of the land" here: Esperantujo, Esperanto Land, is a place of the heart, not a piece of territory on the map unlike the settling of Jews in Palestine, unlike the diaspora where people were forced to move away from a distinct piece of land they considered home. A possible source of this confusion might be found if the Esperanto community of practice is identified with speech communities of traditional minority languages in Europe such as the Welsh in Britain or the Frisians in the Netherlands. However, speech communities are defined not only by language but also by non-linguistic variables such as ethnicity, birthplace, family bonds, religious habits, cooking traditions and so on: no such variables are part of the Esperanto identity. In order to overcome the existence of two ideological parties pro and con "Raumism", a new Manifesto was needed. Some elements of the Raumism had to be integrated with the mainstream neutralism. A new Manifesto was signed in Prague in 1996 and re- mains the final word regarding the language representation of Esperantists. More than twenty years after its publication, there has been no serious ideological debate as to its currency. And with it, for the first time an Esperantist Manifesto was published not only in Esperanto but also in several languages of the world, minority languages included, validating Tonkin's linking of Esperanto to human rights in general and linguistic rights in particular. In particular, Alcalde (2015b) frames the scholarly work on Esperanto in the field of linguistic justice in a way that suggests that post-Raumist ideology is highly compatible with the school of thought of multiculturalism represented by authors like Kymlicka, or Patten's classification of language rights. In the current debate on linguistic justice, Esperanto represents an alternative point of view to the idea that the spread of English as a global lingua franca leads to more social inclusion. In the internal discourse about Esperanto, some supporters even claim that on the contrary, English leads to a kind of global diglossia, increasing the gap between the elites and the masses, while Esperanto can be mastered in considerably short time compared to English, so that this diglottic situation would not appear if Esperanto was more commonly used.

In any case, analysis of the Prague Manifesto shows that Zamenhof's ideals still underlie Esperanto language representation. No more is it considered a commodity by its supporters, as the Declaration of Boulogne seemed to suggest (Gobbo, 2016). In the last few decades attitudes toward multilingualism have deeply changed. According to Caligaris's (2016) sociolinguistic research of Esperanto speakers, multilingualism is considered a positive value per se within the Esperanto community of practice. The importance of language rights also seems to be widely recognized by Esperanto speakers, according to the data. Unfortunately, more comprehensive surveys on this topic are still not available to confirm Caligaris' results. However, Font's survey (2012) of Catalan Esperantists confirms the relatively high degree of multilingualism among Esperanto speakers, which had already been found in previous local studies on German and Flemish Esperantists. On average, an Esperanto speaker's repertoire consists of 3.3 languages, something they are all proud of (Font, 2012, p. 27). The latest generation of Esperanto speakers seems to understand the current situation of mulilingualism in terms of 'glocalization' (Bastardas i Boada, 2012) which consists of globalization, which emphasises the role of English worldwide as no other language in the history of humankind, and localization, where various movements in support of traditional minority languages challenge the Westphalian model of nation-state from within. Parallelly there is support for the rights of new minority communities formed as a result of mobility, in particular, forced migration. Esperanto now is increasingly considered a linguistic tool for communication in a scenario of complex multilingualism, but no longer the one-shot solution for all language problems. Since the time of Lapenna, not to mention 
that of its pioneers, the Esperanto Movement has come a long way.

\section{Conclusions}

Analysis of the Esperanto community's language ideology over the course of more than a century reveals a rich palette of political colours, and a considerable amount of evolution. If religion played a distinct role in Zamenhof's vision, the language representation has tended to downplay it since then. The mainstream Esperanto Movement has always fostered neutralism, as well as the ethnic neutrality postulated by Zamenhof after his original philosophical project, Hillelism, failed. Although his influence is still relevant to the ideological discourse of the language, several contributions were brought in by succeeding leaders. Persecutions during the Second World War had a considerable impact: the left-winged ideas were pushed to the periphery of the Movement, while the existence of the nation-states was no longer challenged. Esperantists nowadays find and form themselves in groups within the concept of nation. Meanwhile, relations between linguistic minorities and Esperanto are still unclear, as Esperanto is the official language of no state, so, in some sense, it is similar to minority languages, and above all it is unclear how it can help the cause of minority languages in concrete terms. Table 1 sums up the main ideological viewpoints within the mainstream Esperanto Movement contrasted with Lanti's Anationalism.

A counter-intuitive finding is that Esperanto's language ideology nowadays seems to be saying that it does not pose a threat to national social cohesion but supports the idea of multilingualism-if it includes Esperanto-as reinforcing mild nationalism, in a framework of multiculturalism and mutual respect for everyone's language diversity. In the current scholarly literature on the actual crisis of the Westphalian model, the contribution of the Esperanto Movement should not be underestimated, as it represents an original perspective on many issues and in particular on linguistic justice.

\section{Acknowledgements}

I thank László Marácz for the interesting discussions we have had on the concept of political neutrality in the 20th century during the past four years. I also thank the editor and the anonymous reviewers for their careful reading of my manuscript and their many insightful comments and suggestions, which helped me to improve it.

\section{Conflict of Interests}

Federico Gobbo is appointed as holder of the Special Chair in Interlinguistics and Esperanto at the University of Amsterdam on behalf of the Universal Esperanto Association (UEA). Usual disclaimers apply.

\section{Funding}

The research leading to these results has received funding from the European Community's Seventh Framework Programme under grant agreement No. 613344 (Project MIME).

Table 1. The importance of nationality and religion within the mainstream Esperanto Movement across time.

\begin{tabular}{|c|c|c|c|c|}
\hline Position & Year & Main level of action & Nationality & Religion \\
\hline Zamenhof's Hillelism & 1901 & Individual > national & $\begin{array}{l}\text { Tolerated } \\
\text { (to be overcome in the long run) }\end{array}$ & $\begin{array}{l}\text { New monotheistic } \\
\text { cult }\end{array}$ \\
\hline Internal idea & 1905 & Underspecified & Respected & Irrelevant \\
\hline Swiss neutralism & 1908 & Individual > national & Ignored & Irrelevant \\
\hline French neutralism & 1911 & Individual < national & Respected & Respected \\
\hline Zamenhof's Homaranismo & 1913 & Individual > national & $\begin{array}{l}\text { Respected } \\
\text { (inside multicultural federations) }\end{array}$ & $\begin{array}{l}\text { Practical } \\
\text { monotheism }\end{array}$ \\
\hline Lanti's Anationalism & 1921 & Individual > national & To be overcome through Esperanto & To be overcome \\
\hline Lapenna's neutralism & 1948 & Individual < national & $\begin{array}{l}\text { Respected } \\
\text { (against Fascism and Communism) }\end{array}$ & Respected \\
\hline Tonkin's neutralism & 1974 & Individual < national & $\begin{array}{l}\text { Respected } \\
\text { (inside language rights for minorities) }\end{array}$ & Irrelevant \\
\hline Raumism & 1980 & Individual > national & $\begin{array}{l}\text { Irrelevant } \\
\text { (Esperanto speakers are a minority) }\end{array}$ & Irrelevant \\
\hline Prague neutralism & 1996 & Individual < national & $\begin{array}{l}\text { Respected } \\
\text { (Esperantism in } 7 \text { key concepts) }\end{array}$ & Irrelevant \\
\hline
\end{tabular}

Notes: years indicate the moments of publications; reformulations thereafter are ignored. 


\section{References}

Alcalde, J. (2015a). The practical internationalism of Esperanto. Per la Pau, 24.

Alcalde, J. (2015b). Linguistic justice: An interdisciplinary overview of the literature (Amsterdam Working Papers in Multilingualism \#3). Retrieved from https://papers.ssrn.com/sol3/papers.cfm?abstract_ id $=2630104$

Astori, D. (2011). Creazione linguistica e identità socionazionale: Da Alessarco di Macedonia all'Isola delle Rose. In P. Valore (Ed.), Multilingualism. Power and knowledge (pp. 145-158). Pisa: Edistudio.

Astori, D. (2015). Metafore nell'esperanto: Una cartina al tornasole eterodossa della moderna riflessione più tradizionale sulle lingue naturali. In D. Astori (Ed.), La metafora e la sua traduzione: Fra riflessioni teoriche e casi applicative (pp. 133-148). Parma: Bottega del libro editore.

Bastardas i Boada, A. (2010). Language and identity policies in the 'glocal' age: New processes, effect, and principles of organization. Barcelona: Institut d'Estudis Autonòmics.

Beaulac, S. (2004). The Westphalian model in defining international law: Challenging the myth. Australian Journal of Legal History, 9.

Berdichevsky, N. (2014). Modern Hebrew: The past and future of a revitalized language. Jefferson, NC: McFarland \& $C$.

Blanke, D. (1989). Planned languages: A survey of some of the main problems. In K. Schubert (Ed.), Interlinguistics. Aspects of the science of planned languages (pp. 63-77). Berlin and New York: Mouton de Gruyter.

Blanke, D. (2006). Interlinguistische Beiträge. Zum Wesen und zur Funktion internationaler Plansprachen. Frankfurt am Main: Peter Lang.

Caligaris, I. (2016). Una lingua per tutti, una lingua di nessun Paese. Una ricerca sul campo sulle identità esperantiste (MA dissertation). Laurea in Scienze Linguistiche, University of Torino, Torino.

Cherpillod, A. (2005). Hillel la saĝulo. Courgenard: La Blancheterie.

Cooke Brown, J. (1960). Loglan. Scientific American, 202, pp. 43-63.

Dietterle, J. (1929). (Ed.). Originala Verkaro de L. L. Zamenhof. Leipzig: Ferdinand Hirt \& Sohn Esperantofako.

Dröge, P. (2016). Moresnet. Opkomst en ondergang van een vergeten buurlandje. Houten and Antwerpen: Unieboek.

Duolingo (2017). Esperanto for English speakers. Duolingo. Retrieved from www.duolingo.com

Eckert, P. (2006). Communities of practice. In Encyclopedia of language and linguistics. Elsevier.

Font, H. A. (2012). Catalan Esperantists: Pacifists in a globalised world. ICIP Working Papers, 3.

Garvía, R. (2015). Esperanto and its rivals: The struggle for an international language. Philadelphia: University of Pennsylvenia Press.

Gishron, J. (1986). Lingvo kaj religio. Studo pri la frua esperantismo kun speciala atento al L. L. Zamenhof. Jerusalem: Sivron.

Gledhill, C. (2000). The grammar of Esperanto: A corpusbased description (2nd ed.). Munich: Lincom Europa.

Gobbo, F. (2012). Alan Turing creator of artificial languages. Alan Turing kreinto de artefaritaj lingvoj. InKoj. Philosophy \& Artificial Languages, 3(2), 181-194.

Gobbo, F. (2016). Approaches to multilingualism of Esperanto speakers. In E. Poláková, S. Ó Riain, \& I. Vančo (Eds), Perspectives of language communication in the EU (pp. 69-80). Nitra: Constantine the Philosopher University of Nitra.

Gobbo, F. (2017). Are planned languages less complex than natural languages? Language Sciences, 60, 36-52.

Gordin, M. D. (2015). Scientific Babel: How science was done before and after global English. Chicago: University of Chicago Press.

Halperin, L. R. (2012). Modern Hebrew, Esperanto, and the quest for a universal language. Jewish Social Studies: History, Culture, Society, 19(1), 1-33.

Holzhaus, A. (1969). Doktoro kaj lingvo Esperanto. Helsinki: Fondumo Esperanto.

Janton, P. (1993). Esperanto: Language, literature, and community. Albany, NY: State University of New York Press.

Korĵenkov, A. (2015). Louis de Beaufront, la dua patro de Esperanto. La Balta Ondo.

Korzhenkov, A. (2010). Zamenhof: The life, works and ideas of the author of Esperanto. New York: Mondial.

Künzli, A. (2010). L. L. Zamenhof (1859-1917): Esperanto, Hillelismus (Homaranismus) und die "jüdische Frage" in Ost- und Westeuropa. Wiesbaden: Otto Harrasowitz Verlag.

Lanti, E. (1922). For la neŭtralismon! Paris: SAT.

Lapenna, I., Lins, U., \& Carlevaro, T. (1974). Esperanto en perspektivo. Rotterdam: Universala EsperantoAsocio.

Large, A. (1985). The artificial language movement. Oxford: Blackwell.

Lins, U. (2017). Dangerous language: Esperanto under Hitler and Stalin. Palgrave.

Maimon, N. Z. (1978). La kaŝita vivo de Zamenhof. Tokio: Japana Esperanto-Instituto.

Matthias, U. (2002). Esperanto-The new Latin for the church and for ecumenism. Antwerpen: Flanda Esperanto-Ligo.

Minnaja, C. (2007). L'esperanto in Italia. Alla ricerca della democrazia linguistica. Padova: II Poligrafo.

Okrent, A. (2010). In the land of invented languages: A celebration of linguistic creativity, madness, and genius. New York: Spiegel \& Grau.

Peterson, D. J. (2015). The art of language invention: From horse-lords to dark elves, the words behind the 
world-building. New York: Penguin.

Pietiläinen, J. (2010). Plurlingvismo kaj Esperanto: Ideologia ŝanĝiĝo en la Esperanto-movado. D. En Blanke \& U. Lins (Eds.), La arto labori kune: festlibro por Humphrey Tonkin (pp. 781-792). Rotterdam: UEA.

Sikosek, Z. M. (2005). Sed homoj kun homoj: Universalaj Kongresoj de Esperanto 1905-2005. Rotterdam: UEA.

Sikosek, Z. M. (2006). Die neutrale Sprache. Eine politische Geschichte des Esperanto-Weltbundes. Bydgoszcz: Skonpres.

Simons, G. F., \& Fennig, C. D. (2017). (Eds.). Ethnologue: Languages of the world (20th ed.). Dallas: SIL International.
Stria, I. (2016). Inventing languages, inventing worlds: Towards a linguistic worldview for artificial languages (PhD dissertation). Wydział Neofilologii UAM w Poznaniu, University Adam Mickiewicz, Poznań.

Tonkin, H. (2006). Lingvo kaj popolo. Aktualaj problemoj de la Esperanto-movado. Rotterdam: UEA.

Van Parijs, P. (2011). Linguistic justice for Europe and for the world. Oxford: Oxford University Press.

Yaguello, M. (1991). Lunatic lovers of language: Imaginary languages and theirs inventors. London: The Athlone Press.

Zamenhof, L. L. (1915). Post la Granda Milito. Alvoko al la diplomatoj. After the Great War. An appeal to the diplomatists. In The British Esperantist (pp. 51-54).

\section{About the Author}

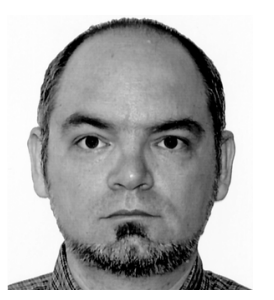

Federico Gobbo is Full Professor at the University of Amsterdam and Visiting Professor at the University of Torino. He participates in the EU-7FP funded project MIME (Mobility and Inclusion in Multilingual Europe) at the University of Milano-Bicocca. He has worked in various Universities in Italy, the Netherlands and China. His research interests include sociolinguistics, interlinguistics, constructive linguistics and philosophy of information. The Esperanto phenomenon is one of his main research interests, and he has published research results about it since 1998. 